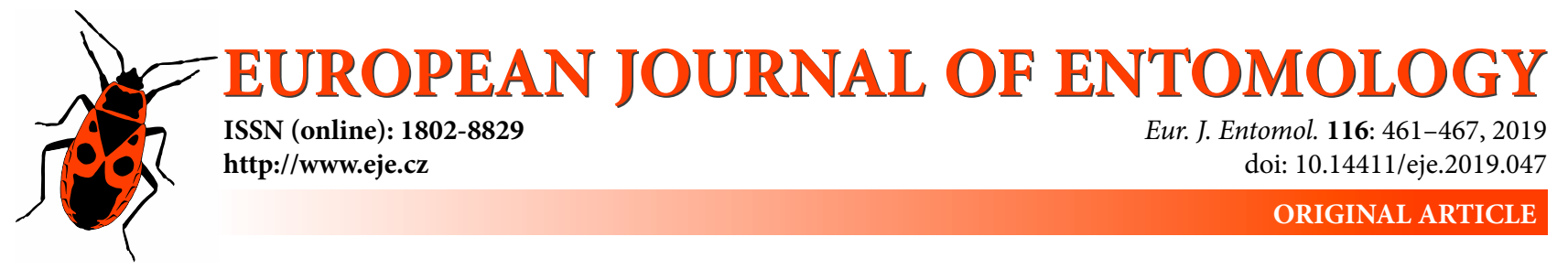

\title{
Diversity of ant assemblages (Hymenoptera: Formicidae) in an urban environment in Cameroon during and after colonization of the area by Wasmannia auropunctata
}

\author{
Paul Serge mbenoun masse ${ }^{1}$, Maurice Tindo $^{2}$, Champlain DJiÉto-LORdon $^{1}$, Ruth MONY ${ }^{1}$ and Martin KenNe $^{2}$ \\ ${ }^{1}$ Laboratoire de Zoologie, Département de Biologie et Physiologie Animales, Faculté des Sciences, Université de Yaoundé 1 , \\ BP 812, Yaoundé, Cameroun; e-mails: masseserge@yahoo.fr/smbenoun@uy1.uninet.cm, ruthmony@yahoo.fr, \\ djieto_champlain@yahoo.ca \\ ${ }^{2}$ Département de Biologie des Organismes Animaux, Faculté des Sciences, Université de Douala, BP 24157, Douala, \\ Cameroun; e-mails: tindodouala@yahoo.com, medoum68@yahoo.fr
}

Key words. Hymenoptera, Formicidae, ants, Wasmannia auropunctata, Pheidole megacephala, diversity, colonization, urban environment, Cameroon

\begin{abstract}
Invasive species disrupt the organization and functioning of many ant communities. Little is known about ant assemblages formerly in areas invaded by the little fire ant. In this study, we surveyed the same areas and compared the ant communities there when an invasive species first colonized the areas and 10 years later, using the same methodology (quadrat and baiting). A total of 83,299 worker ants from 17 species or morphospecies, in 4 subfamilies and 10 genera were recorded in the two periods sampled. Seven ant species were found to co-occur with $W$. auropunctata while 12 species were collected in the same area 10 years later, with no $W$. auropunctata recorded in any of the traps. In the absence of $W$. auropunctata, the number and diversity of ant species increased and the ant communities were dominated by the African big-headed ant, Pheidole megacephala. Our findings indicate that the disappearance of $W$. auropunctata is probably related to population increases in $P$. megacephala associated with dramatic changes in landscape. Further studies at other invaded locations should be carried out in order to reveal the generality of these patterns throughout this country.
\end{abstract}

\section{INTRODUCTION}

Invasive species are recognized worldwide as one of the most important threats to biodiversity after habitat fragmentation (Rabitsch, 2011; Wittman, 2014; Orrock et al., 2015; Bertelsmeier et al., 2016). Biological invaders penetrate natural ecosystems and often reduce the diversity of native species (Human \& Gordon, 1996; Hoffmann et al., 1999), affect other organisms both directly and indirectly (Meek, 2000; Jourdan et al., 2001; Laakkonen et al., 2001; Fisher et al., 2002) and severely disrupt the organization of many native communities (Mack et al., 2000; Sanders et al., 2003).

Ants are among the most problematic invasive species, threatening native biodiversity, and negatively impacting ecosystem and human health (Elton, 1958; Mack et al., 2000; Holway et al., 2002; Lach \& Hooper-Bui, 2010; Rabitsch, 2011; Orrock et al., 2015). Many reports attribute the success of invasive species to behavioural and genetic changes (Hölldobler \& Wilson, 1990; Passera, 1994; Holway, 1998; McGlynn, 1999; Suarez et al., 1999; Tsutsui et al., 2000; Tsutsui \& Suarez, 2003), release from natural enemies and new opportunities for resources in their intro- duced ranges (Clark et al., 1982; Settle \& Wilson, 1990; Ulloa Chacón, 1990; Mack et al., 2000; Shea \& Chesson, 2002; Le Breton et al., 2005). According to Holway et al. (2002), six ants are recognized as the most widespread and damaging invasive species: Anoplopepis gracilipes (yellow crazy ant), Linepithelma humile (Argentine ant), Pheidole megacephala (African big-headed ant), Solenopsis invicta (red imported fire ant), Solenopsis geminata (tropical fire ant) and Wasmannia auropunctata (little fire ant).

Wasmannia auropunctata Roger, 1893 is one of the most harmful invasive species in the world (Wetterer \& Porter, 2003). Native to Central and South America, W. auropunctata has been introduced throughout the West Indies, Australia, Israel, Italy, Pacific islands groups and West Africa (Wetterer, 2013). In Cameroon, $W$. auropunctata was first reported in cocoa plantations along the Kribi-Ebolowa road (de Miré, 1969). Since then, it has successfully spread into southern and eastern Cameroon (Tindo et al., 2012), where it has severely reduced the abundance and richness of native ant species (Mbenoun et al., 2017).

The invasive success of exotic species can vary substantially over time from population explosions to population 

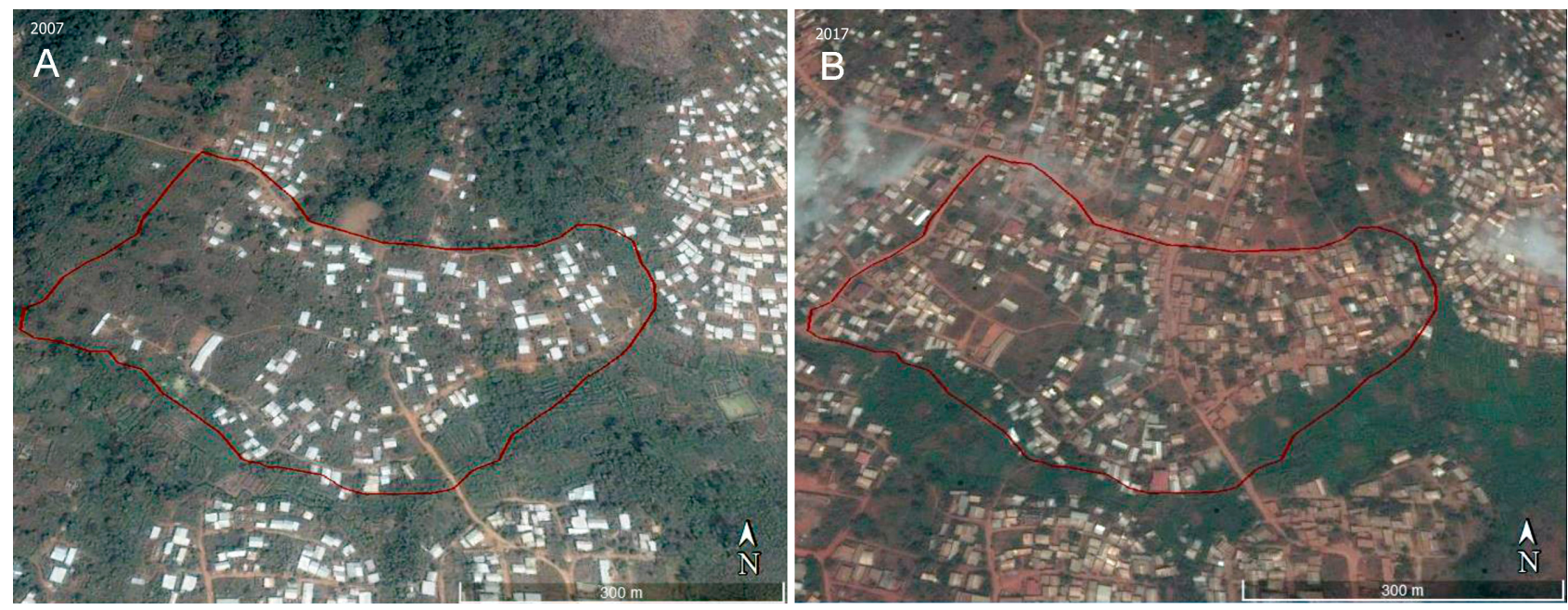

Fig. 1. Map showing the location of the study site in 2007 (A) and in 2017 (B).

collapses or dramatic population declines. These phenomena have been reported for a wide range of invasive species, including snails and crayfish (Simberloof \& Gibbons, 2004; Sandström et al., 2014). With regard to invasive ants, Morrison (2002) reports that red fire ants (Solenopsis invicta) decreased in Texas over 12 years. Similarly, populations of Argentine ant (Linepithelma humile) have decreased at $40 \%$ of the sites surveyed, with a mean survival time of 14 years (Cooling et al., 2012). More recently, yellow crazy ant (Anoplolepis gracilipes) populations have declined or disappeared in Australia without human intervention (Cooling \& Hoffmann, 2015).

Although invasive ants may initially exterminate native ants, ant communities have recovered in environments previously invaded by Solenopsis invicta (Morrison, 2002; Calixto et al., 2007), Pheidole megacephala (Torres \& Snelling, 1997) and Linepithema humile (Wetterer et al., 2006; Cooling et al., 2012). However, with regard to $W$. auropunctata, little is known about the ant assemblages in areas several years after they were colonized by this ant. In this study, we hypothesized that native ant communities in an area may recover some time after being colonized by an invasive species.

\section{MATERIAL AND METHODS}

\section{Study area}

This study was first carried out in 2007 and repeated in 2017 in Biyem-Assi ( $\left.3^{\circ} 51^{\prime} 83^{\prime \prime} \mathrm{N}, 1^{\circ} 27^{\prime} 76^{\prime \prime} \mathrm{E}\right)$ (Fig. 1), an urban district of Yaoundé (political capital of Cameroon). The vegetation in Yaoundé was semi-deciduous forest, but currently is a mixture of relic forest on summits of hills and garden crops (urban agriculture) along river and inland valleys. The wet season is from March to June, followed by a short dry season from July to the end of August, a short wet season from September to midNovember and a long dry season from mid-November to February. Average annual rainfall is about $1,500 \mathrm{~mm}$. The mean annual relative humidity is $79.5 \%$. Mean air temperature ranges from 19.2 to $28.6^{\circ} \mathrm{C}$. Wasmannia auropunctata was first detected at this location in 1998 during a preliminary survey of its distribution in Cameroon (Tindo et al., 2012). Since the first survey in 2007 , the landscape of this location has dramatically changed and is now characterized by build-up areas, fewer green spaces and less vegetation

\section{Sampling methods}

The methodology used by Mbenoun et al. (2017) for sampling in 2017 was replicated as closely as possible at the same plots where $W$. auropunctata were previously found. Eight transects were established extending in four directions (East, West, South and North) from areas previously colonized by the invasive ant and those not colonized. At each previously colonized area, starting from randomly selected points and going in each of the four cardinal directions, two parallel lines ( $150 \mathrm{~m}$ long and $2 \mathrm{~m}$ wide) spaced $10 \mathrm{~m}$ apart were established. Sampling points were established every $10 \mathrm{~m}$ along the transect lines giving a total of 30 samples ( 15 samples $\times 2$ transects $\times 1$ direction of invasion). These transects were surveyed once a month over a period of 12 months. Ant species richness and occurrence were monitored at the same areas previously sampled in 2007 that were colonized by $W$. auropunctata, using ground baiting and quadrat sampling (Bestelmeyer et al., 2000).

\section{Ground baiting}

Baits consisted of $20 \mathrm{~cm} \times 20 \mathrm{~cm}$ square plastic trays containing a mixture of honey $30 \%$, tuna $50 \%$ and soya oil $20 \%$. Fifteen bait stations were placed along each transect line $10 \mathrm{~m}$ apart. Ants were checked on the bait after $30 \mathrm{~min}$ to $60 \mathrm{~min}$ and collected using forceps and a pooter. Samples were stored in vials containing $70 \%$ ethanol and transferred to the laboratory for counting and identification.

\section{Quadrat sampling}

Fifteen $1 \mathrm{~m}^{2}$ quadrats were established along the second transect line (10 m apart). Within each, we actively searched for ants in rotten logs and stumps, dead and alive branches and twigs, low vegetation and under stones for $15 \mathrm{~min}$. A total of 180 quadrats were sampled in each cardinal direction during the sampling period. Ants found were collected using forceps and a pooter, stored in vials containing $70 \%$ ethanol and transferred to the laboratory for counting and identification.

\section{Specimen processing}

In the laboratory of Zoology at the University of Yaoundé I, ants were identified to species level (or to morpho-species) using keys from Hölldobler \& Wilson (1990) and Bolton (1994) for genera, and the web site "Ants of sub-Saharan African" (Taylor, 


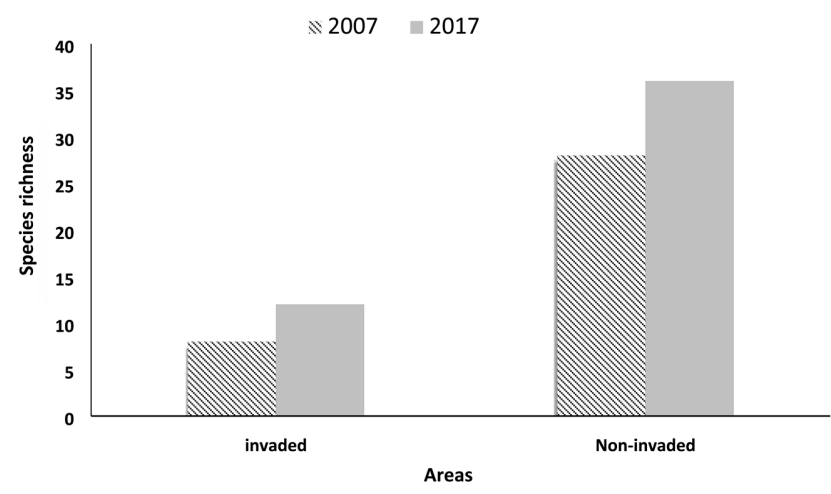

Fig. 2. Species richness recorded in areas invaded and not invaded by $W$. auropunctata in 2007 and 2017.

2011) for species. Ant specimens were mounted on card board triangles and then kept as a reference collection in the laboratory.

\section{Statistical analysis}

For analysis, data were entered on a matrix in the form of presence-absence data, a fundamental unit of study in community ecology and biogeography. The percentage of occurrence was used to estimate the relative abundance of all species at each site. To estimate the species richness in the two periods sampled, Margalef richness index (R1) and Menhinick index (R2) were calculated using the following formulae:

$$
\mathrm{R} 1=\frac{\mathrm{S}-1}{\ln (\mathrm{N})} \text { and } \mathrm{R} 2=\frac{\mathrm{S}}{\sqrt{\mathrm{N}}}
$$

where $\mathrm{S}$ is the number of species and $\mathrm{N}$ is the total number of individuals.

To evaluate the diversity in the two periods sampled, ShannonWeaver diversity index $\left(\mathrm{H}^{\prime}\right)$ and Pielou's equitative index $\left(\mathrm{J}^{\prime}\right)$ were used while evenness was analysed using Simpson dominance index (D).

$$
\mathrm{H}^{\prime}=-\sum_{\mathrm{i}=1}^{\mathrm{S}^{*}}\left(\mathrm{p}_{\mathrm{i}} * \log _{2} \mathrm{p}_{\mathrm{i}}\right)
$$

where $p$ is the proportion of individuals in the $i^{\text {th }}$ order.
$\mathrm{J}^{\prime}=\frac{\mathrm{H}^{\prime}}{\mathrm{H}_{\max }}=\frac{\mathrm{H}^{\prime}}{\ln (\mathrm{S})}$

where $\mathrm{H}_{\text {max }}=\log _{2}(\mathrm{~S})$.

$\mathrm{D}=\sum_{\mathrm{i}=1}^{\mathrm{S}} \frac{\mathrm{n}_{\mathrm{i}}\left(\mathrm{n}_{\mathrm{i}}-1\right)}{\mathrm{N}(\mathrm{N}-1)}$

where $n_{i}=$ the number of individuals of species " $i$ " and $N=$ the total number of individuals.

Then these parameters for 2007 and 2017 were compared using the parametric Student's $t$ test when the data were normally distributed. All statistical tests were carried out using SPSS software version 16.0 for Windows.

\section{RESULTS}

\section{Structure of the ant assemblages}

A total of 83,299 worker ants belonging to 17 species or morphospecies in 4 subfamilies and 10 genera were recorded in the two periods sampled (Table 1). Myrmicinae was the most species-rich subfamily with 11 species, followed by Formicinae ( 3 species) and Dolichoderinae (2 species). The most species-rich genus was Pheidole (4 species) followed by Monomorium (3 species) and Camponotus and Tapinoma with 2 species each.

\section{Ant composition in the two periods}

In 2007, eight species of ants were collected in invaded areas (Fig. 2). Wasmannia auropunctata was the most frequent species (140 occurrences; 89.17\%) (Fig. 3A) and co-occurred with seven species: $P$. megacephala (10 occurrences; 6.37\%), Monomorium bicolor (2 occurrences; $1.27 \%$ ) and Myrmicaria opaciventris, Tapinoma carininotum, Paratrechina longicornis, Tetramorium simillimum, Solenopsis geminata (1 occurrence, $0.64 \%$ each). Ten years later, 12 ant species were collected with no $W$. auorpunctata recorded in any of the traps. The most common species was P. megacephala (74.74\%) (Fig. 3B), followed

Table 1. List of the species of ants occurring in the area studied when (2007) and after (2017) it had been colonized by W. auropunctata.

\begin{tabular}{|c|c|c|c|}
\hline Subfamilies / species & Native range & 2007 & 2017 \\
\hline \multicolumn{4}{|l|}{ Dolichoderinae } \\
\hline Tapinoma carininotum Weber, 1943 & AF & 5 & 14 \\
\hline Tapinoma sp. & AF & 0 & 4 \\
\hline Formicinae & AF & & \\
\hline Camponotus (Tanaemyrmex) maculatus (Fabricius, 1782) & $\mathrm{AF}$ & 0 & 8 \\
\hline Camponotus (Tanaemyrmex) acvapimensis Mayr, 1862 & AF & 0 & 14 \\
\hline Paratrechina longicornis (Latreille, 1802) & AF & 5 & 0 \\
\hline Myrmicinae & AF & & \\
\hline Monomorium guineense (Bernard, 1953) & AF & 0 & 10 \\
\hline Monomorium bicolor Emery, 1877 & $\mathrm{AF}$ & 8 & 6 \\
\hline Myrmicaria opaciventris Emery, 1893 & $\mathrm{AF}$ & 9 & 2542 \\
\hline Pheidole megacephala (Fabricius, 1793) & $\mathrm{AF}$ & 24 & 45006 \\
\hline Pheidole minima Mayr, 1901 & $\mathrm{AF}^{*}$ & 0 & 13 \\
\hline Pheidole tenuinodis Mayr, 1901 & AF & 0 & 4 \\
\hline Pheidole sp.4 & AF & 0 & 4 \\
\hline Solenopsis geminata (Fabricius, 1804) & CS, SA & 5 & 0 \\
\hline Tetramorium simillimum (Smith, 1851) & $\mathrm{AF}$ & 5 & 0 \\
\hline Wasmannia auropunctata Roger 1863 & CS, SA & 35609 & 0 \\
\hline \multicolumn{4}{|l|}{ Ponerinae } \\
\hline Hypoponera cognata (Santschi, 1912) & $\mathrm{AF}$ & 0 & 4 \\
\hline
\end{tabular}
$\mathrm{AF}$ - Africa, $\mathrm{AF}^{*}$ - Africa and endemic in Cameroon, CS - Central America, SA - South America. 


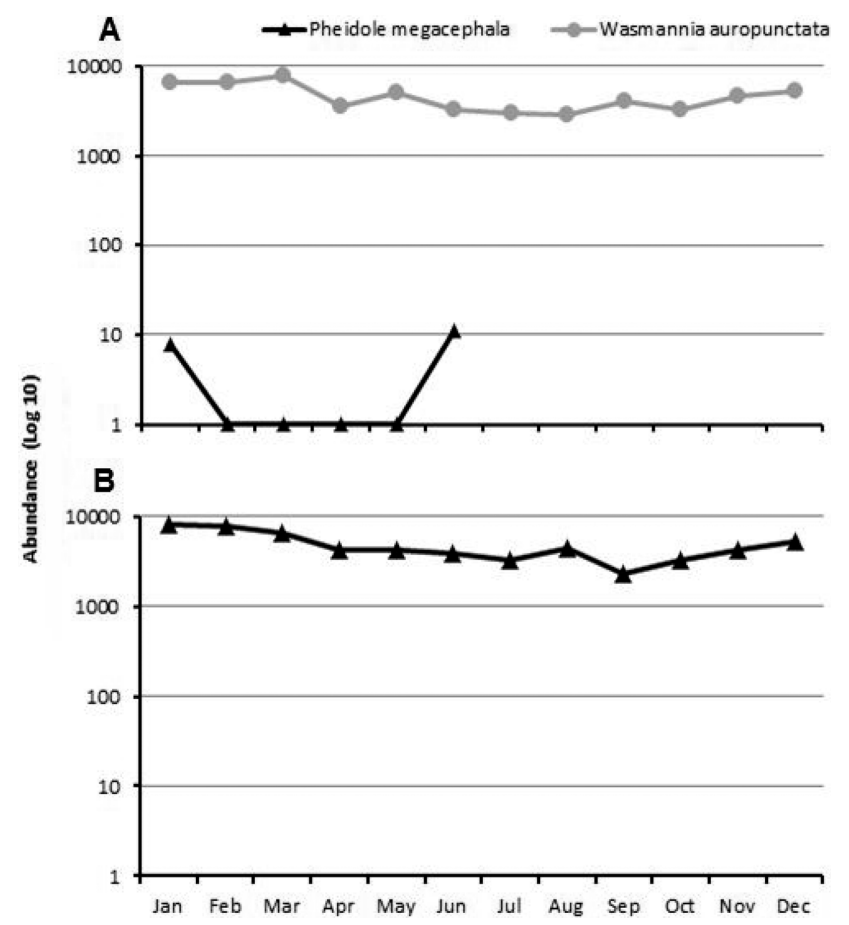

by Myrmicaria opaciventris (10.77\%) and Camponotus acvapimensis $(3.93 \%)$.

In the non-invaded areas, 28 and 36 species of ants were collected in 2007 and 2017, respectively (Table 2). The most common species were Pheidole megacephala, (35.63\% and $62.57 \%)$ followed by Solenopsis geminata $(20.61 \%$ and $3.55 \%)$ and Paratrechina longicornis (10.71\% and $1.89 \%$ ) in 2007 and 2017, respectively.

\section{Species turnover, diversity and evenness}

Three ant species (Paratrechina longicornis, Solenopsis geminata and Tetramorium simillimum) that were present in initially invaded areas were absent in 2017. In contrast, eight species (Tapinoma sp., Camponotus acvapimensis, Camponotus maculatus, Monomorium guineense, Pheidole tenuinodis, P. minima, Pheidole sp.4 and Hypoponera cognata) that were absent in initially invaded areas were present in 2017. The occurrence of two species $P$. mega-

Fig. 3. Abundance $\left(\log _{10}\right)$ of Pheidole megacephala and Wasmannia auropunctata at sites when $W$. auropunctata was present (2007) (A) and absent (2017) (B).

Table 2. Relative frequency of the different species of ants in areas invaded and not invaded by W. auropunctata in 2007 and 2017.

\begin{tabular}{|c|c|c|c|c|}
\hline \multirow{2}{*}{ Subfamilies / species } & \multicolumn{2}{|c|}{2007} & \multicolumn{2}{|c|}{2017} \\
\hline & Invaded & Not-invaded & Invaded & Not-invaded \\
\hline \multicolumn{5}{|l|}{ Aenictinae } \\
\hline Aenictus decolor (Mayr, 1879) & - & 0.43 & - & 0.07 \\
\hline \multicolumn{5}{|l|}{ Cerapachyinae } \\
\hline Lioponera coxalis (Arnold, 1929) & - & 0.01 & - & - \\
\hline \multicolumn{5}{|l|}{ Dolichoderinae } \\
\hline Tapinoma carininotum Weber, 1943 & 0.64 & 11.09 & 2.9 & 2.08 \\
\hline Tapinoma sp. & - & - & 0.21 & 0.01 \\
\hline Technomyrmex albipes (Smith, 1861) & - & 0.06 & - & 0.01 \\
\hline \multicolumn{5}{|l|}{ Dorylinae } \\
\hline Dorylus (Anomma) nigricans Illiger, 1802 & - & 0.26 & - & 0.05 \\
\hline Dorylus (Dorylus) sp. & - & 0.56 & - & 0.09 \\
\hline \multicolumn{5}{|l|}{ Formicinae } \\
\hline Camponotus (Myrmotrema) sp.1 & - & 0.25 & - & 0.05 \\
\hline Camponotus (Myrmotrema) sp.2 & - & 0.10 & - & 0.02 \\
\hline Camponotus (Tanaemyrmex) maculatus (Fabricius, 1782) & - & - & 0.83 & 0.01 \\
\hline Camponotus (Tanaemyrmex) acvapimensis Mayr, 1862 & - & - & 3.93 & 0.05 \\
\hline Lepisiota sp.1 & - & 0.07 & - & 0.01 \\
\hline Lepisiota sp.2 & - & 0.11 & - & 0.09 \\
\hline Lepisiota sp.3 & - & - & _ & 0.21 \\
\hline Paratrechina longicornis (Latreille, 1802) & 0.64 & 10.71 & - & 1.89 \\
\hline \multicolumn{5}{|l|}{ Myrmicinae } \\
\hline Monomorium pharaonis (Linnaeus, 1758) & - & 6.36 & - & 1.74 \\
\hline Monomorium guineense (Bernard, 1953) & - & 0.14 & 2.07 & 0.04 \\
\hline Monomorium sp.3 & - & - & - & 0.06 \\
\hline Monomorium bicolor Emery, 1877 & 1.27 & 2.06 & 1.24 & 0.78 \\
\hline Myrmicaria opaciventris Emery, 1893 & 1.27 & 4.50 & 10.77 & 3.57 \\
\hline Pheidole sp.2 & - & 0.08 & - & 0.07 \\
\hline Pheidole megacephala (Fabricius, 1793) & 6.37 & 35.63 & 74.74 & 62.57 \\
\hline Pheidole speculifera Emery, 1877 & - & 5.12 & - & 0.86 \\
\hline Pheidole minima Mayr, 1901 & - & - & 2.68 & 0.25 \\
\hline Pheidole tenuinodis Mayr, 1901 & - & - & 0.21 & 0.01 \\
\hline Pheidole sp.4 & - & - & 0.21 & 0.06 \\
\hline Solenopsis geminata (Fabricius, 1804) & 0.64 & 20.61 & - & 3.55 \\
\hline Tetramorium simillimum (Smith, 1851) & 0.64 & 0.22 & - & 0.11 \\
\hline Tetramorium sp.2 & - & 0.07 & - & 0.03 \\
\hline Tetramorium aculeatum (Mayr, 1866) & - & 0.19 & - & 0.03 \\
\hline Tetramorium longicorne Forel, 1907 & - & 0.08 & - & 0.17 \\
\hline Tetramorium coloreum Mayr, 1901 & - & 0.05 & - & 0.01 \\
\hline Wasmannia auropunctata Roger 1863 & 89.17 & - & - & \\
\hline \multicolumn{5}{|l|}{ Ponerinae } \\
\hline Odontomachus troglodytes Santschi, 1914 & - & 0.38 & - & 0.06 \\
\hline Brachyponera sennaarensis (Mayr, 1862) & - & 0.67 & - & 0.11 \\
\hline Paltothyreus tarsatus (Fabricius, 1798) & - & 0.17 & - & 0.03 \\
\hline Hypoponera cognata (Santschi, 1912) & - & - & 0.21 & - \\
\hline \multicolumn{5}{|l|}{ Pseudomyrmecinae } \\
\hline Tetraponera ledouxi Terron, 1969 & - & - & - & 0.01 \\
\hline
\end{tabular}


Table 3. Species richness, diversity, equitability and evenness in areas invaded by $W$. auropunctata in 2007 and in 2017 when this species had disappeared.

\begin{tabular}{lccccc}
\hline \multirow{2}{*}{ Parameters } & \multicolumn{2}{c}{ Invaded area } & \multicolumn{3}{c}{ Student's $t$ test } \\
\cline { 2 - 6 } & 2007 & 2017 & $t$ & $d f$ & $P$ \\
\hline Species richness (S) & 8 & 12 & & & \\
Individuals (N) & 35670 & 47629 & & & \\
Margalef (R1) & 0.66 & 1.02 & & & \\
Menhinick (R2) & 0.04 & 0.05 & & & \\
Simpsom (D) & 0.9983 & 0.8563 & 25.32 & 11 & $>0.05 \mathrm{~ns}$ \\
Shannon (H') & 0.007994 & 0.3495 & 72.04 & 11 & $<0.001^{* * *}$ \\
Pielou (J') & 0.003638 & 0.1363 & 59.34 & 11 & $<0.001^{* * *}$ \\
\hline
\end{tabular}

ns - non-significant; ${ }^{* * *} P<0.001-$ highly significant difference at $5 \%$ confidence interval.

cephala and $M$. opaciventris was significantly greater in 2017.

Species richness and number of individuals were higher in $2017(\mathrm{~N}=47629 ; \mathrm{S}=12)$ than in $2007(\mathrm{~N}=35670$; $\mathrm{S}$ $=8)$. Despite this difference in species richness, Margalef and Menhinick richness estimators indicate that these values were very low and tended towards zero. The ant communities were more diverse and heterogeneous in 2017 $\left(\mathrm{H}^{\prime}=0.349 ; \mathrm{J}^{\prime}=0.136\right)$ than in $2007\left(\mathrm{H}^{\prime}=0.007 ; \mathrm{J}^{\prime}=\right.$ $0.003)$, with significant differences in both the ShannonWeaver (Parametric t test: $t=72.04 ; P<0.001$ ) and Pielou indices (Parametric t test: $t=59.34 ; P<0.001$ ) (Table 3). In 2007 , the ant communities were almost mono-specific and dominated by $W$. auropunctata $(\mathrm{D}=0.99)$, whereas P. megacephala dominated ant communities in 2017 (D = $0.85)$. There was no difference in species evenness in the two years sampled (Parametric t test: $t=25.32 ; P>0.05$ ).

\section{DISCUSSION}

Our results highlight differences in the structure of native ant assemblages in the presence and absence of $W$. auropunctata. Indeed, in areas colonized by this ant, native ant species richness was very low, whereas ten years later when $W$. auropunctata was no longer present it was much higher. In areas invaded by this species not only have a reduced species richness but also disassembled communities (Mack et al., 2000; Sanders et al., 2003). However, the abundance of many invasive species may vary substantially over time and recovery or resurgence of native ant communities is possible after they decline in abundance or disappear (Torres \& Snelling, 1997; Morrison, 2002; Wetterer et al., 2006; Calixto et al., 2007).

The present study documented the disappearance of $W$. auropunctata in an urban district in Cameroon. A previous ecological study in the same area indicated the contraction of population along different invasion fronts during a 6-year period (Tindo et al., 2012). Although population collapses or substantial declines are recorded for other invasive species of ants, such as: Linepithema humile (Argentine ant) (Wetterer et al., 2006), Anoplolepis gracilipes (yellow crazy ant) (Abbott \& Green, 2007), Pheidole megacephala (big-headed ant) (Torres \& Snelling, 1997; Wetterer et al., 2006), Solenopsis geminata (tropical fire ant) (Wilson, 2005) and Solenopsis invicta (imported red fire ant) (Morrison, 2002), the mechanisms driving the declines are still unclear. Several hypotheses have been suggested, such as, infection by local pathogens or attack by parasites, fire, pesticides, migration, over exploitation of resources, climate, changes in the food availability, vegetation and population bottlenecks in introduced ranges (Haines \& Haines, 1978; Russell-Smith et al., 1997; Wetterer et al., 1998, 2006; Mikheyev \& Mueller, 2007; Lester \& Gruber, 2016). Other biotic factors, like competitive exclusion of $W$. auropunctata by dominant native ants might account for the disappearance of $W$. auropunctata in both previously invaded and surrounding areas. The competitive exclusion principle predicts that interspecific competition results in the elimination or extinction of one of two species that occur together without niche differentiation (Webb et al., 2002; Bøhn et al., 2008). In accordance with our previous findings (Mbenoun et al., 2017) and other studies (Tennant, 1994; Le Breton et al., 2003), some dominant species, particularly ants of the genus Pheidole, can co-occur in the same plots with $W$. auropunctata and may keep its population densities low. In addition, $P$. megacephala is numerically the dominant species in ant communities in its native range (Dejean et al., 2008; Mbenoun et al., 2017). In contrast, $W$. auropunctata never dominates ant communities in its native range and several species of Pheidole are important competitors and may significantly reduce its population density (Levings \& Franks, 1982; Tennant, 1994).

Although P. megacephala dominates native communities of ants and exhibits unicolonial social structure even in its native range, which is key factor determining its ecological dominance (Fournier et al., 2012), this species is able to coexist with other native ants with similar foraging and dietary requirements. Dejean et al. (2008) point out that only colonies of Solenopsis geminata, Dorymyrmex pyramicus and Dorichoderus bispinosus resisted raids by $P$. megacephala in its introduced range, whereas 11 of 12 species in its native range resisted raids by the workers of P. megacephala.

In conclusion, this study revealed that the structure of ant assemblages change over time. It highlights that native ant communities can be transiently invaded by $W$. auropunctata and might recover over time. The population increase in African big-headed ant $P$. megacephala and dramatic changes in the landscape between 2007 and 2017 might account for the disappearance of $W$. auropunctata in the area studied. Therefore, further studies at other invaded sites should be carried out in order to reveal the consistency of these results and understand the mechanisms that cause population declines or local extinctions of the little fire ant.

ACKNOWLEDGEMENTS. We would like to thank the Royal Museum of Central Africa, Belgium, for help with the identification of the ants and three anonymous referees for their helpful comments on the manuscript.

\section{REFERENCES}

Aвbott K.L. \& Green P.T. 2007: Collapse of an ant-scale mutualism in a rainforest on Christmas Island. - Oikos 116: $1238-1246$. 
Bestelmeyer B., Agosti D., Alonso L.E., Brandao C.R.F., Brown J.W.L., Delabie J.H.C. \& Silvestre R. 2000: Field techniques for the study of ground dwelling ants. In Agosti J.D., Alonso L.E. \& Schultz T. (eds): Ants: Standard Methods for Measuring and Monitoring Biodiversity. Smithsonian Institution Press, Washington, pp. 122-154.

Bertelsmeier C., Ollier S., Avril A., Blight O., Jourdan H. \& Courchamp F. 2016: Colony-colony interactions between highly invasive ants. - Basic Appl. Ecol. 17: 106-114.

BøHn T., Amundsen P. A. \& Sparrow A. 2008: Competitive exclusion after invasion? - Biol. Invasions 10: 359-368.

Bolton B. 1994: Identification Guide to the Ant Genera of the World. Harward University Press, Cambridge, $222 \mathrm{pp}$.

Calixto A.A., Harris M.K. \& Barr C. 2007: Resurgence and persistence of Dorymyrmex flavus after reduction of Solenopsis invicta buren with a broadcast bait. - Environ. Entomol. 36: $549-554$.

Clark D.B., Guayasamín C., Pazmiño O., Donoso C. \& De VilLACIS Y.P. 1982: The tramp ant Wasmannia auropunctata: autecology and effects on ant diversity and distribution on Santa Cruz Island, Galapagos. — Biotropica 14: 196-207.

Cooling M. \& Hoffmann B.D. 2015: Here today, gone tomorrow: declines and local extinctions of invasive ant populations in the absence of intervention. - Biol. Invasions 17: 3351-3357.

Cooling M., Hartley S., Sim D.A. \& Lester P.J. 2012: The widespread collapse of an invasive species: Argentine ants (Linepithema humile) in New Zealand. - Biol. Lett. 8: 430-433.

Dejean A., Moreau C.S., Kenne M. \& Leponce M. 2008: The raiding success of Pheidole megacephala on other ants in both its native and introduced ranges. - C. R. Biol. 331: 631-635.

De Miré B. 1969: Une fourmi utilisée au Cameroun dans la lutte contre les mérides du cacaoyer: Wasmannia auropunctata Roger. - Café Cacao Thé 13: 209-212.

Elton C.S. 1958: The Ecology of Invasions by Animals and Plants. Methuen, London, 253 pp.

Fisher R.N., Suarez A.V. \& Case T.J. 2002: Spatial patterns in the abundance of the coastal horned lizard. - Conserv. Biol. 16: $205-215$.

Fournier D.A., Tindo M., Kenne M., Mbenoun Masse P.S., Van Bossche V., De Coninck E. \& Aron S. 2012: Genetic structure, nestmate recognition and behaviour of two cryptic species of the invasive big-headed ant Pheidole megacephala. - PLoS ONE 7: e31480, 16 pp.

Haines I.H. \& Haines J.B. 1978: Pest status of the crazy ant, $A n-$ oplolepis longipes (Jerdon) (Hymenoptera: Formicidae), in the Seychelles. - Bull. Entomol. Res. 68: 627-638.

Hoffmann B.D., ANDERSEN A.N. \& HiLl G.J.E. 1999: Impact of an introduced ant on native forest invertebrates: Pheidole megacephala in monsoonal Australia. - Oecologia 120: 595-604.

Hölldobler B. \& Wilson E.O. 1990: The Ants. The Belknap Press of Harward University Press, Cambridge, 712 pp.

Holway D.A. 1998: Factors governing rate of invasion: a natural experiment using Argentine ants. - Oecologia 115: 206-212.

Holway D.A., Lach L., Suarez A., Tsutsui N.D. \& Case T.J. 2002: The causes and consequences of ant invasions. - Annu. Rev. Ecol. Evol. Syst. 33: 181-233.

Human K.G. \& Gordon D.M. 1996: Exploitation and interference competition between the invasive Argentine ant, Linepithema humile, and native ant species. - Oecologia 105: 405-412.

Jourdan H., SAdLIER R.A. \& BAuER A.M. 2001: Little fire ant invasion (Wasmannia auropunctata) as a threat to New Caledonian lizards: evidences from a Sclerophyll forest (Hymenoptera: Formicidae). - Sociobiology 38: 283-301.

LAAKKonen J., Fisher R.N. \& CASE T.J. 2001: Effect of land cover, habitat fragmentation, and ant colonies on the distribution and abundance of shrews in southern California. - J. Anim. Ecol. 70: $776-788$.

Lach L. \& Hooper-Bui L.M. 2010: Consequences of ant invasions. In Lach L.D. \& Abbott C. (eds): Ant Ecology. Oxford Univeristy Press, Oxford, pp. 231-286.

Le Breton J., Chazeau J. \& Jourdan H. 2003: Immediate impacts of invasion by Wasmannia auropunctata (Hymenoptera: Formicidae) on native litter ant fauna New Caledonian rainforest. - Austral. Ecol. 28: 204-209.

Le Breton J., Jourdan H., Chazeau J., Orivel J. \& Dejean A. 2005: Niche opportunity and ant invasion: The case of Wasmannia auropunctata in a New Caledonian rain forest. $-J$. Trop. Ecol. 21: 93-98.

Lester P.J. \& Gruber M.A.M. 2016: Booms, busts and population collapses in invasive ants. - Biol. Invasions 18: 3091-3101.

LeVINGS S.C. \& Franks N.R. 1982: Patterns of nest dispersion in a tropical ground ant community. - Ecology 63: 338-344.

Mack R.N., Simberloff D., Lonsdale W.M., Evans H., Clout M. \& BAZZAZ F.A. 2000: Biotic invasions: causes, epidemiology, global consequences, and control. — Ecol. Appl. 10: 689-710.

Mbenoun Masse P.S., Tindo M., Kenne M., Tadu Z., Mony R. \& DлIÉTo-LoRdon C. 2017: Impact of the invasive ant Wasmannia auropunctata (Formicidae: Myrmicinae) on ant diversity in southern Cameroon. - Afr. J. Ecol. 55: 423-432.

McGlynN T.P. 1999: The worldwide transfer of ants: geographical distribution and ecological invasions. - J. Biogeogr. 26: 535-548.

MeEk P.D. 2000: The decline and current status of the Christmas Island shrew Crocidura attenuata trichura on Christmas Island, Indian Ocean. - Aust. Mammal. 22: 43-49.

Mikheyev A.S. \& Mueller U.G. 2007: Genetic relationships between native and introduced populations of the little fire ant Wasmannia auropunctata. — Divers. Distrib. 13: 573-579.

MoRrison L.W. 2002: Long-term impacts of the invasion of an arthropod community by the red imported fire ant, Solenopsis invicta. - Ecology 83: 2337-2345.

Orrock J.L., Dutra H.P., Marquis R.J. \& Barber N. 2015: Apparent competition and native consumers exacerbate the strong competitive effect of an exotic plant species. - Ecology 96: 1052-1061.

PASSERA L. 1994: Characteristics of tramp species. In Williams D.F. (ed.): Exotic Ants: Biology, Impact, and Control of Introduced Species. Westview Press, Boulder, CO, pp. 23-43.

RABITSCH W. 2011: The Hitchhiker's guide to alien ant invasions. - Biocontrol 56: 551-572.

Russell-Smith J., Ryan P.G. \& DuRieu R. 1997: A LANDSATT MSS-derived fie history of Kakadu National Park, monsoonal northern Australia, 1980-1994: seasonal extent, frequency and patchiness. - J. Appl. Ecol. 35: 829-846.

Sanders N.J., Gotelli N.J., Heller N.E. \& Gordon D.M. 2003: Community disassembly by an invasive species. - Proc. Natl. Acad. Sci. U.S.A. 100: 2474-2477.

Sandström A., Anderson M., Asp A., Bohman P., Edsman L., Engdahl F., Nyström P., Stenkerg M., Hertonsson L., VRalSTAD T. \& GRANELI W. 2014: Population collapses in introduced non-indigenous crayfish. — Biol. Invasions 16: 1961-1977.

SETTLE W.H. \& WiLSON L.T. 1990: Invasion by the variegated leafhopper and biotic interactions: parasitism, competition and apparent competition. - Ecology 71: 1461-1470.

SheA K. \& Chesson P. 2002: Community ecology theory as a framework for biological invasions. - Ecol. Evol. 17: 170176.

SimberLoff D. \& Gibbons L. 2004: Now you see them, now you don't! - population crashes of established introduced species. - Biol. Invasion 6: 161-172. 
Suarez A.V., Tsutsui N.D., Holway D.A. \& Case T.J. 1999: Behavioral and genetic differentiation between native and introduced populations of the Argentine ant. - Biol. Invasions 1: $43-53$.

TAYLOR B. 2011: Ant of Africa. URL: http://antbase.org/ants/2011 (last accessed 18 Sep. 2011).

TennANT L.E. 1994: The ecology of Wasmannia auropunctata in primary tropical Costa Rica and Panama. In Williams D.F. (ed.): Exotic Ants: Biology, Impact and Control of Introduced Species. Westview Press, Boulder, CO, pp. 80-90.

Tindo M., Mbenoun Masse P.S., Kenne M., Mony R., Orivel J., Doumtsop Fotio A., Fotso Kuate A., Duieto-Lordon C., Fomena A., Estoup A., Dejean A. \& Foucaud J. 2012: Current distribution and population dynamics of the little fire ant supercolony in Cameroon. - Insectes Soc. 59: 175-182.

Torres J.A. \& SNelling R.R. 1997: Biogeography of Puerto Rican ants: a non-equilibrium case? - Biodivers. Conserv. 6: 1103-1121.

Tsutsui N.D. \& SuARez A.V. 2003: The colony structure and population biology of invasive ants. - Conserv. Biol. 17: 48-58.

Tsutsui N.D., Suarez A.V., Holway D.A. \& Case T.J. 2000: Reduced genetic variation and the success of an invasive species. _ Proc. Natl. Acad. Sci. U.S.A. 97: 5948-5953.
Ulloa Chacón P. 1990: Biologie de la reproduction chez la petite fourmi de feu Wasmannia auropunctata (R.) (Hymenoptera: Formicidae). MSc Thesis, Université de Lausanne, $161 \mathrm{pp}$.

Webb C.O., Ackerly D.D., Mcreek M.A. \& Donoghue M.J. 2002: Phylogenies and community ecology. - Annu. Rev. Ecol. Evol. Syst. 33: 475-505.

WetTerer J.K. 2013: Worldwide spread of the little fire ant, Wasmannia auropunctata (Hymenoptera: Formicidae). - Terr. Arthropod Rev. 6: 173-184.

Wetterer J.K. \& Porter S.D. 2003: The little fire ant, Wasmannia auropunctata: distribution, impact, and control. - Sociobiology 42: 1-41.

Wetterer J.K., Banko P.C., Laniawe L.P., Slotterback J.W. \& BrenNer G.J. 1998: Non-indigenous ants at high elevations on Mauna Kea, Hawaii. - Pac. Sci. 52: 228-236.

Wetterer J.K., Espadaler X., Wetterer A.L., Aguin-Pombo D. \& Franquinha-Aguiar A.M. 2006: Long-term impact of exotic ants on the native ants of Madeira. - Ecol. Entomol. 31: 358-368.

WILSON E.O. 2005: Environment: early ant plagues in the New World. - Nature 433: 32.

WitTMan S.E.W. 2014: Impacts of invasive ants on native ant communities (Hymenoptera: Formicidae). - Myrmecol. News 19: $111-123$.

Received April 25, 2019; revised and accepted November 20, 2019 Published online December 6, 2019 